\title{
Blast Analysis on In-Filled Steel Tube Columns
}

\author{
Karthik N Ganiga ${ }^{1}$ | Ibrahim Mahzeen ${ }^{1} \mid$ Mohammed Safan $^{1}$ | Shaikh Fazil M U ${ }^{1}$ Shilpa $S^{2}$
}

${ }^{1}$ Students, Civil Engineering Department, Srinivas University college of Engineering and Technology, Mukka Mangaluru, Karnataka , India

${ }^{2}$ Assistant Professor, Civil Engineering Department, Srinivas University college of Engineering and Technology, Mukka Mangaluru, Karnataka, India

To Cite this Article

Karthik N Ganiga, Ibrahim Mahzeen, Mohammed Safan, Shaikh Fazil M U and Shilpa S, "Blast Analysis on In-Filled Steel Tube Columns", International Journal for Modern Trends in Science and Technology, Vol. 06, Issue 06, June 2020, pp::50-53; https://doi.org/10.46501/IJMTST060612

Article Info

Received on 28-April-2020, Revised on 20-May-2020, Accepted on 25-May-2020, Published on 04-June-2020.

\section{ABSTRACT}

In recent years, a large number of studies have been carried out to investigate the behaviours of concrete filled double skin steel tube (CFDST) members due to its increasing popularity in the construction industry. This project aims to study on ultra-high performance concrete filled double-skin tubes subjected to blast loading with cross section being square for both inner and outer steel tubes using ANSYS software. It is evident that the proposed CFDST column was able to withstand a large blast load without failure so that it has the potential to be used in high-value buildings as well as critical infrastructures. The steel tubes and concrete work together well and integrity of steel concrete interface is maintained. Steel tubes in inner and outer can acts as permanent formwork and primary reinforcement. ANSYS results shows that the CFDA column can withstand applied blast load.

KEYWORDS: CFDST Column, steel casing, Blast load

Copyright (C) 2014-2020 International Journal for Modern Trends in Science and Technology

DOI: https://doi.org/10.46501/IJMTST060612

\section{INTRODUCTION}

Due to increase in the threat of terrorist activity, many efforts have been made to mitigate blast effect on structures so that they can remain unaffected by severe explosion accidents without catastrophic disaster, thus to decrease the number of human casualties. Using of blast barriers which are the indirect means to protect resistless infrastructures and people inside them are used widely. Although such indirect methods cannot productively prevent attacks initiated by suicide bombers or suitcase bombs as it was indicated by several recent terrorist attacks. Consequently, there is an immediate need to directly strengthen the blast-resistance of important structures through using new structural types or new materials.

Recently, concrete-filled steel tubes, as a comparatively new steel concrete composite structure, have fascinated enormous amount of awareness in the civil engineering applied due to their high strength and excellent longevity. A concrete filled double-skin steel tube (CFDST) is usually constructed by filling concrete in-between two concentrically placed steel tubes. Passive confining pressure on the concrete filler resulted from the steel tubes which the main advantage of this structural type. The strength and plasticity of the concrete filler can be outstanding signify although the buckling of steel tubes can be retorted, if not completely prevented, by the concrete filler which can be caused due to confining pressure. 
Usually, hollow steel tubes under transverse impact loading have failed a head of time due to severe local buckling or even transport before the material can develop its peak strength; if not,the concrete filler can effectively prevent steel buckling, consequently allowing the steel tube to progress its full strength and resulting in less deflection or structural destruction for the concrete filled steel tubes. Similarly as compared to conventional RC columns, breaching and spalling destruction of concrete are unlikely to occur in concrete filled steel tubes when subjected to blast loading. The majority of the recent studies on CFDST columns mainly use normal strength concrete filler. Nevertheless, modern trends of constructing high-rises and long-extent bridgeshave been made to blast load on structure at the distance of $1500 \mathrm{~mm}$ from the structure.

\section{OBJECTIVES OF THE PROJECT}

- The present investigation aims to estimate the ultimate strength and study the behaviour of in-filled steel tube column.

- The in-filling of a steel tube column, concrete produces certain mechanical interaction, which is highly beneficial. The in-filled concrete increases its buckling strength under blast loading.

- To develop interaction diagram for various thickness of steel tube for different cross section of a column subjected to blast loading conditions.

- Responses of different structural systems are studied in terms of displacements due to beams and column.

\section{MethodS AND Methodology}

For the analysis, ANSYS 13 was used for the hollow beam having outer dimension $210 \mathrm{~mm} x$ $210 \mathrm{~mm}$ and inner dimension $100 \mathrm{~mm} \times 100 \mathrm{~mm}$ and the length of the beam $2500 \mathrm{~mm}$ was used.

Boundary condition is given for the column as simply supported. To ensure the both ends are simply supported for the column, all degree of freedom is selected.Outside the column, $50 \mathrm{Kg}$ mass of explosive has been made to blast load on structure at the distance of $1500 \mathrm{~mm}$ from the structure.
Table. 1 Material Properties

\begin{tabular}{|l|c|c|c|}
\hline $\begin{array}{l}\text { Property } \\
\text { Name }\end{array}$ & Symbol & Values & Units \\
\hline Grade & $\mathrm{f}_{\mathrm{ck}}$ & 25 & $\mathrm{~N} / \mathrm{mm}^{2}$ \\
\hline $\begin{array}{l}\text { Young's } \\
\text { Modulus }\end{array}$ & $\mathrm{E}$ & 29.58 & $\mathrm{GPa}$ \\
\hline $\begin{array}{l}\text { Poisson } \\
\text { ratio }\end{array}$ & $v$ & 0.19 & --- \\
\hline Density & $\rho$ & 2500 & $\mathrm{~kg} / \mathrm{m}^{3}$ \\
\hline
\end{tabular}

\section{VAlidation OF MODEL}

Validation model consists of a beam having particular dimension. And we have material properties for concrete. In this project we have taken boundary condition of beam is simply supported beam with two point loading condition. The stress values which is obtained in ANSYS are compared with manual values and we have got errors of $5 \%$.

Finally, by comparing manual values with ANSYS values, its found that, the elements, meshing and the boundary conditions that are used in the ANSYS models are accurate and can be used in determining the failure load of composite beam column

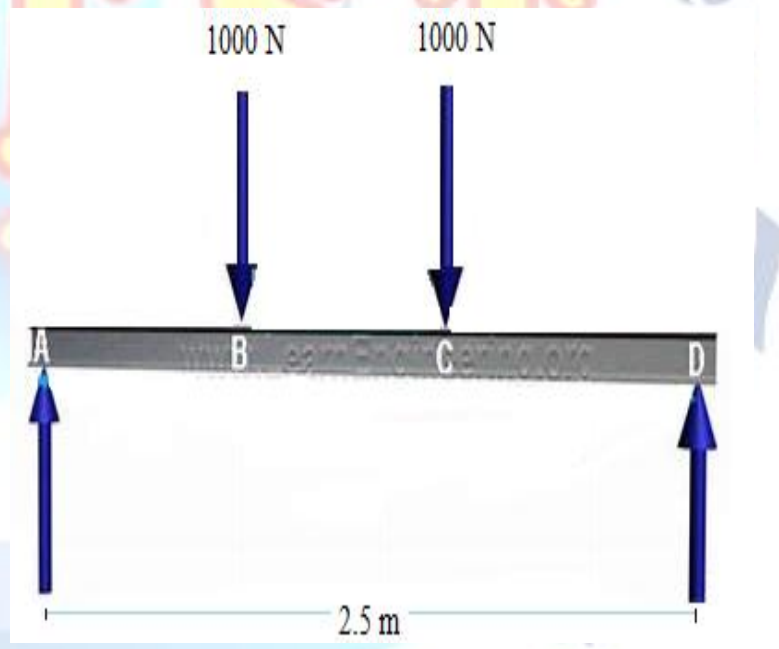

Fig. 1 2D hollow beam section

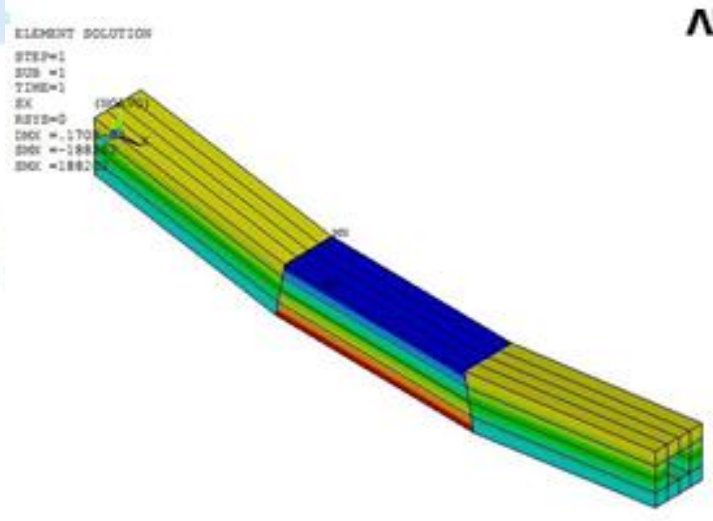

$\mathbf{N}$

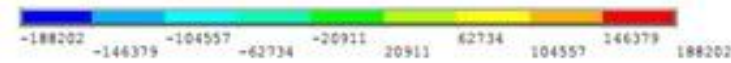

Fig.2 Stress values for hollow beam section 


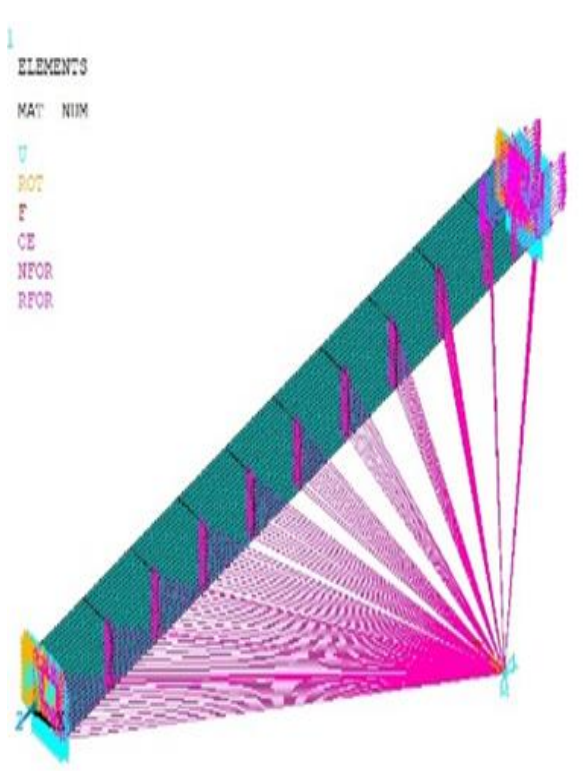

ANSYS

Fig 3 Boundry Conditions applied for beam

\section{RESULTS AND DISCUSSIONS}

For the simulations carried out, we found shear stress in $\mathrm{x}$ direction, $\mathrm{y}$ direction, $\mathrm{z}$ direction, $\mathrm{xy}$ direction, $y z$ direction and $\mathrm{zx}$ direction, among these direction $\mathrm{zx}$ direction shown the better results.

\section{A. Inside casing}

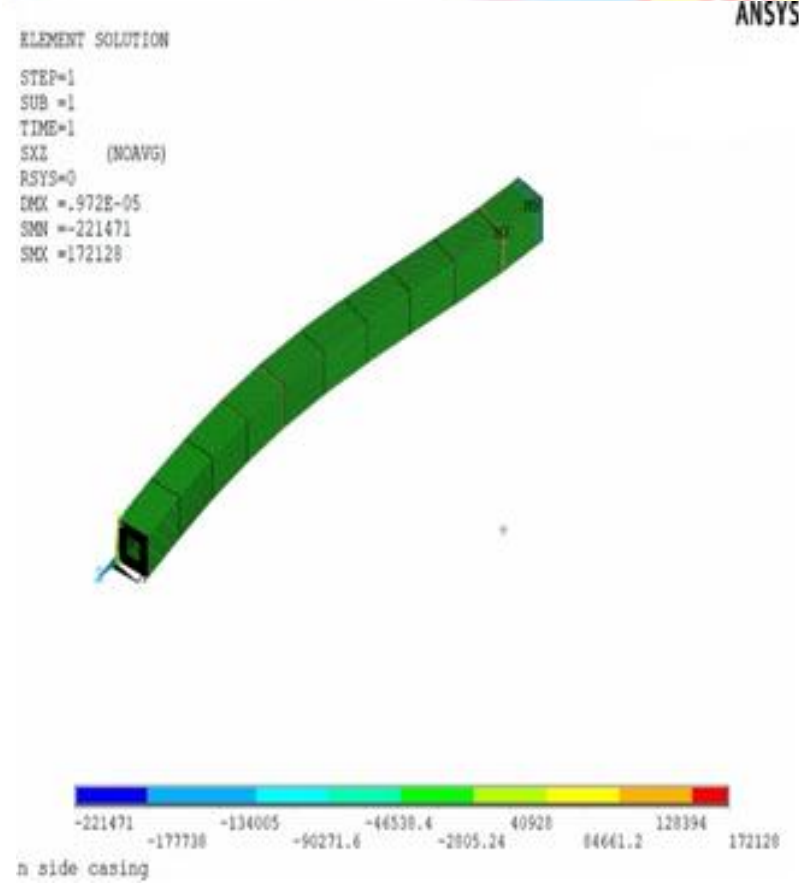

Fig. 4 Inside casing along $z x$ direction

Fig. 4 shows the inside casing of thickness 5.5 $\mathrm{mm}$ along $\mathrm{zx}$-direction. From ANSYS software, there is a displacement of $0.00972 \mathrm{~mm}$ in a column and shear stress is equal to $1,72,128 \mathrm{~N} / \mathrm{m}^{2}$ and the corresponding Force $=5869.56 \mathrm{~N}$

\section{B. No casing}

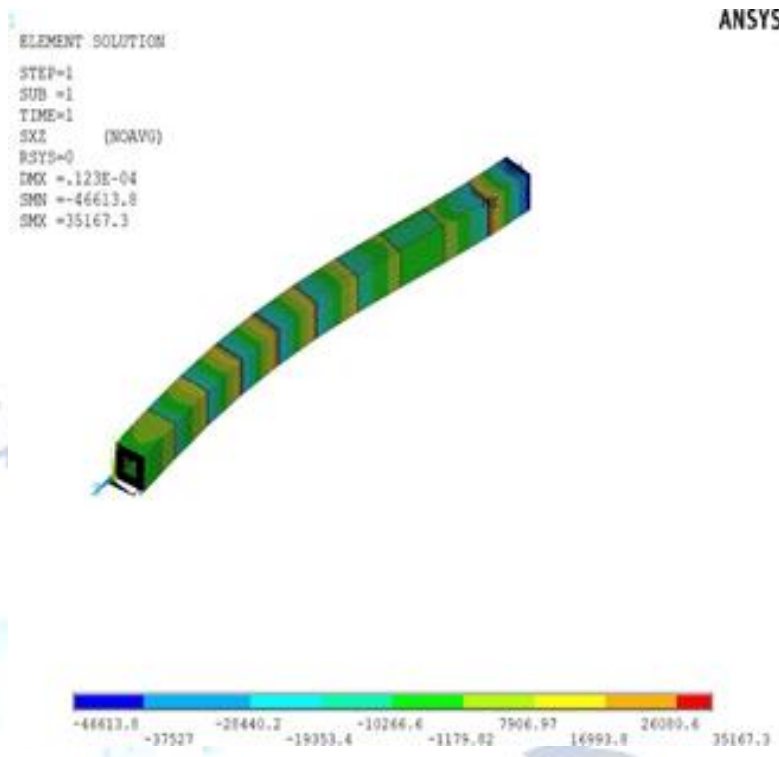

Fig. 5 No casing along $\mathrm{zx}$ direction

Fig. 5 shows the No casing along zx-direction. From ANSYS software, there is a displacement of $0.0123 \mathrm{~mm}$ in a column and shear stress is equal to $35,167.3 \mathrm{~N} / \mathrm{m}^{2}$ and the corresponding Force $=$ $1199.20 \mathrm{~N}$.

\section{Out side casing}

Fig. 6 shows the outside casing of thickness 5.5 $\mathrm{mm}$ along $\mathrm{zx}$-direction. From ANSYS software, there is a displacement of $0.0064 \mathrm{~mm}$ in a column and shear stress is equal to $1,13,529 \mathrm{~N} / \mathrm{m}^{2}$ and the corresponding Force $=3,871.34 \mathrm{~N}$

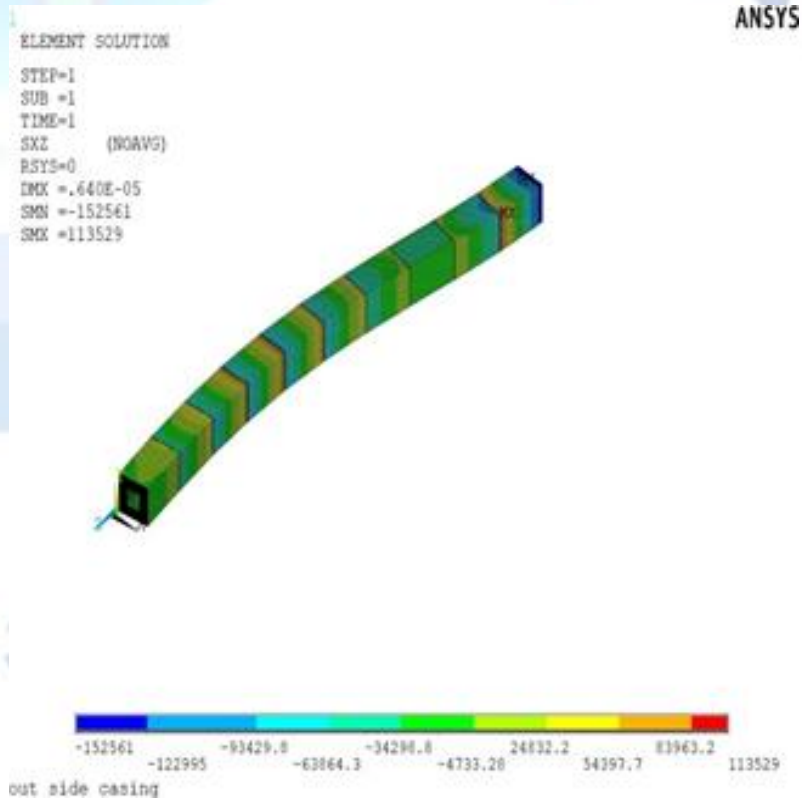

Fig. 6 Out-side casing along zx direction 


\section{Two side casing}

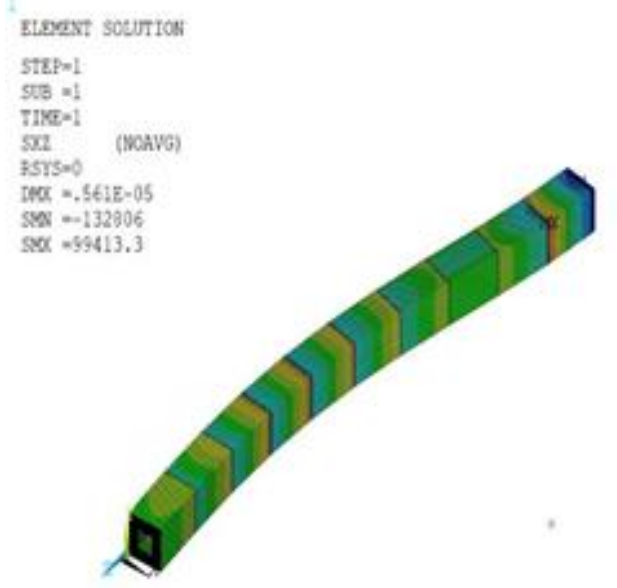

ANSYS

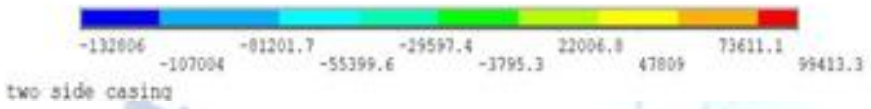

Fig. 7 Two-side casing along zx direction

Fig. 7 shows the two-side casing of thickness 5.5 $\mathrm{mm}$ along zx-direction. From ANSYS software, there is a displacement of $0.00561 \mathrm{~mm}$ in a column and shear stress is equal to $99,413.3 \mathrm{~N} / \mathrm{m}^{2}$ and the corresponding Force $=3,389.99 \mathrm{~N}$.

\section{Conclusion}

This paper has presented study on the performance of concrete-filled double-skin steel tube (CFDST) columns under blast loading using ANSYS software. The following conclusions can be drawn based on the software results:

- ANSYS results shows that the CFDA column can withstand applied blast load.

- By comparing with different casing of steel tubes, the use of $5.5 \mathrm{~mm}$ thick steel tube for two-side casing in the CFDST specimens remarkably reduced the residual deflection where as the reduction in the maximum deflection was much less in percentage.

- While comparing to single sided tube casing, out side casing of steel tubes gives lesser displacement value compared to inner.

- Results of the analysis showed that shear stress is maximum along $\mathrm{zx}$-direction and along this direction it is able to resist the blast load when the column was exposed to explosion.

- The Concrete filled double steel tube column resist more load compared to normal concrete column.

\section{ACKNOWLEDGMENT}

I express profound gratitude to my team member and our beloved guide who helped me to complete this project.

\section{REFERENCES}

[1] FangruiZhang, Chengqing Wu , Xiao-Ling Zhao, Amin Heidarpour, Zhongxian Li "Experimental and numerical study of blast resistance of square CFDST columns with steelfibre reinforced concrete", Engineering Structures 149 (2017), pg.50-63.

[2] Aoude H, Dagenais FP, Burrell RP, Saatcioglu M. "Behavior of ultra-high performance fiber reinforced concrete columns under blast loading”. Int J Impact Eng 2015;80: pg.185-202.

[3] Zhang F, Wu C, Zhao XL, Xiang H, Li ZX, Fang Q, Liu Z, Zhang Y, Heidarpour A, Packer JA. "Experimental study of CFDST columns infilled with UHPC under close-range blast loading”. Int J Impact Eng 2016;93: pg.184-95.

[4] Ngo T, Mohotti D, Remennikov A, Uy B. "Numerical simulations of response of tubular steel beams to close-range explosions". J Constr Steel Res 2015;105: pg.151-63.

[5] Aoude H, Dagenais FP, Burrell RP, Saatcioglu M. "Behavior of ultra-high performance fiber reinforced concrete columns under blast loading”. Int J Impact Eng 2015;80: pg.185-202.

[6] Huang H, Han L-H, Zhao X-L. "Investigation on concrete filled double skin steel tubes (CFDSTs) under pure torsion". J Constr Steel Res 2013;90: pg.221-34.

[7] Yi N-H, Kim J-HJ, Han T-S, Cho Y-G, Lee JH."Blast-resistant characteristics of ultrahigh strength concrete and reactive powder concrete". Constr Build Mater 2012;28(1): pg.694-707.

[8] Huang H, Han L-H, Tao Z, Zhao X-L. "Analytical behaviour of concrete-filled double skin steel tubular (CFDST) stub columns". J Constr Steel Res 2010;66 (4): pg.542-55. 